\title{
Organizational Structure and Employee's Performance: A Study of Brewing Firms in Nigeria
}

\author{
Malik Shahzad Shabbir \\ Center of Professional Excellence (Lecturer) \\ mshahzad786.pk11@gmail.com
}

\begin{abstract}
This study sought to assess the effect of organizational structure on employee's performance in brewing firms in Nigeria. The purpose of the study is to determine whether there is appropriate structure in Nigeria brewing firms and the extent it has contributed to their employees' performances. The population of the study is 6468 being the total staff strength of the five brewing firms in Nigeria Stock Exchange while the sample size was extracted from the population using Taro Yamane method. This study used descriptive type of survey design and structured questionnaire was used to generate data. Descriptive statistics, correlation and t-statistics, was adopted fo $r$ analysis of data and hypotheses testing. The result of the study revealed that nature of hierarchical layers has significant positive effect on the employee's performance of brewing firms; that technology has significant positive effect on the employee's performance of brewing firms; that internal and external boundaries has significant positive effect on the employee's performance of brewing firms; and that formalization significantly affect employee's performance positively. In view of the above findings, the study concludes that adopting appropriate structure is the fulcrum on which employees' performance of brewing firms revolves. The study therefore recommends among others that Nigeria firms should give more serious attention in designing an appropriate structure that must match all units and component parts of organization to facilitate employee's performance.
\end{abstract}

Keywords: Organizational Structure, Organizational layers, formalization, internal and external boundaries, appropriate technology, Employee's performance

\section{INTRODUCTION}

\section{Background of The Study}

There is hardly any organization that does not have profit and growth as its main objectives. The growth of a firm is principally measured on the percentage of market share captured and client served. By deciding how to approach the markets and Customers, employees are place into different strategic positions to execute the strategies and pursue objectives established by the organization. The placement of organizational members into strategic positions of responsibility with authority with a view to achieving organizational objectives is structuring, hence organizational structure is sine qua non to continuous existence of every organization. Designing structure that fits company needs is a major challenge because appropriate structure determines performance of organization. Empirical evidence by Weir (1995) in his effort to establish the relationship between organizational structure and corporate performance concludes that firms that adopted appropriate structure yield higher profits than those that do not while Williams (1997) confirms a positive relationship between organizational structure and strategic planning. However, every structure has its advantages and disadvantages structure is depended on the type of organization. 
This study develops a research framework that examines relationships among various structural dimensions and employees performance in brewing industry in Nigeria. Four aspects of organizational structure are considered: The number of layers in hierarch of the organization, the nature of formalization, the nature of internal and external boundaries that exist in the organization and the nature of technology (appropriate) adopted by the organization. The employee's performance is represented by Supervisor's rating, Quality and quantity, Goal accomplishment, Efficient and effective, Dependable and enthusiastic, Ability and capability. Given the importance of structure to the performance survival, and sustainability of companies and contributions of the brewing sector to the economy, this research therefore deems it necessary to investigate whether appropriate structure is a critical success factor for success of brewing firms in Nigeria and the extent it has helped in the performance of its employees.

\section{Statement of the Problem}

The brewing sector is faced with mixed performance. Evidences from the subsector confirm that quite a number of brewing firms are performing very poorly, in some cases, they goes into liquidation, while few others are performing excellently well using all known performance indicators, for instance, Nigeria breweries and Guinness breweries have been paying dividend to its shareholders consistently for the past twenty years. Besides payment of dividend, almost all other performance indicators have been on the positive trend. However, the excellent performances of few of them are still worrisome as about $70 \%$ of brewing firms went under within the last twenty years. The essence of this study is to determine whether adopting appropriate structure is one of the critical success factors that supports those firms that are performing well in the sector and the extent to which appropriate structure has help the performance of its employee. However, studies have established that efficient and effective performance depend on the designing and adoption of a fitting structure by the organization, in other words, no effective and efficient organization if the structure of the organization does not support the people who work within the system that provide the key element to determine its success.

\section{Objectives of the Study}

The main trust of this study was to assess the effect of organizational structure on employee performance of brewing firms in Nigeria. Drawn from the above broad objective are the following specific objectives:

1. To establish the effect of number of layers in the organizational hierarchy on the performance of brewing firms in Nigeria.

2. To determine the effect of nature of formalization on the performance of brewing firms in Nigeria.

3. To investigate the effect of loose internal and external boundaries on the performance of brewing firms in Nigeria.

4. To ascertain the effect of appropriate technology on the performance of brewing firms in Nigeria

\section{Research Questions}

1. To what extent does the number of layers in the organizational hierarchy affect the performance of brewing firms in Nigeria?

2. What is the effect of nature of formalization on the performance of brewing firms in Nigeria?

3. To what extent does a loose internal and external boundary affect the performance of brewing firms in Nigeria?

4. What is the effect of appropriate technology on the performance of brewing firms in Nigeria? 
Organizational Structure and Employee's Performance: A Study of Brewing Firms in Nigeria

\section{Hypotheses}

Based on the highlighted research objectives and questions, the following research hypotheses were formulated to guide the research for solutions and answers to the problems:

$\mathbf{H o}_{\mathbf{1}}$ : Number of layers in the organizational hierarchy does not have significant effect on the performance of brewing firms in Nigeria.

$\mathbf{H o}_{2}$ : Nature of formalizationdoes not have significant effect on the performance of brewing firms in Nigeria.

$\mathbf{H o}_{3:}$ A loose internal and external boundary does not have significant effect on the performance of brewing firms in Nigeria.

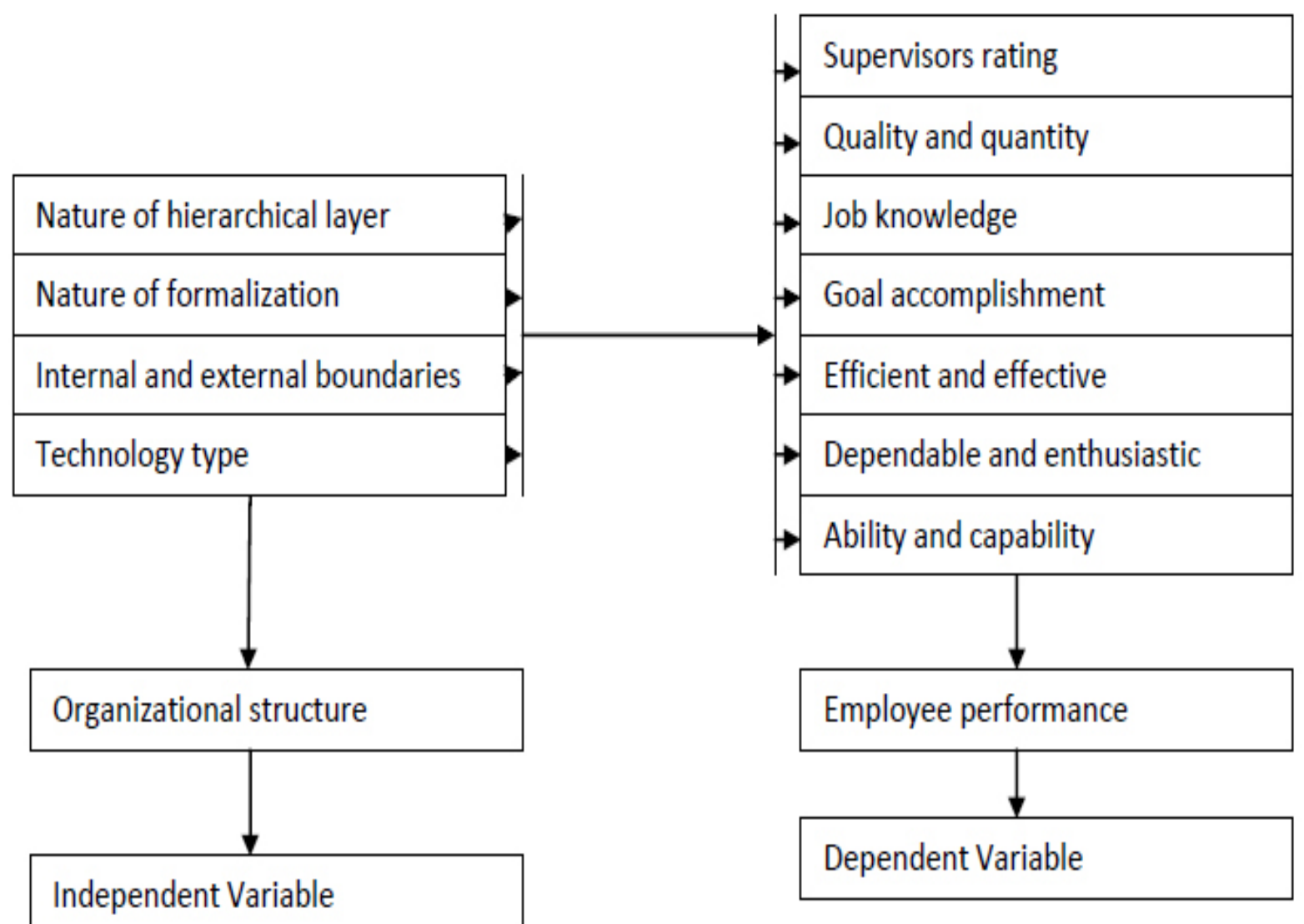

Fig.1: Organizational Structure and Employee performance framework

Source: Researcher's Design 2016

\section{LITERATURE REVIEW}

\section{Conceptual Review}

Organizational structure is how job is formally divided, grouped and coordinated (Sablynski 2003). It is the anatomy of the organization, providing a foundation within which organizations function. However, Nnabuife (2009) visualizes organizational structure as the setting up a structure or mending an already existing one to suit the organizational environment and the demands of technology. From the views of Nnabuife, structure is a factor of technology. Organizational structure influences the way in which work flows in a company, therefore, 
Organizational Structure and Employee's Performance: A Study of Brewing Firms in Nigeria

different design or structure can help or hinder different strategic objectives and also aid or hinder employees in their role. Structure can as well dictate the means by which strategies are formed. However, employees performance in brewing industry in Nigeria examined by various structural dimensions. Four aspects of organizational structure are: the number of layers in the hierarchy, the nature of formalization, loose/blurred internal and external boundaries and appropriate technology. These dimensions can make or mar the effect of structure on employees' performance if not appropriately situated.

\section{Number of Layers in the Hierarchy}

The more layers in a firm, the more complex the structure of the organization, the more complex the structure, the more difficult coordination and integration of organization member become. The recent trend towards flatter organizations is a tacit acknowledgment that complexity will influence the flexibility, and can frustrate an organization's ability to compete in dynamic environment (Nahm, 2003). Lesser layer in organizational hierarchy facilitate decision making. The ease of decision-making refers in the operation who are more likely to know the actual situation that necessitated the decision. Engaging lower cadre in decision making encourages belongingness on the part of the employee. Some Scholars maintain that there are merits of systems with few layers over one with many layers. Macduffie et al,(1995) suggests that as firms operate in a dynamic environment, they need a structure that has with few layers in hierarchy, enables a high level of integration of organizational members (Damanpour,1991) a decentralized decision-making (Vickery,1993) and quick response (Pine,1993).

\section{Nature of Formalization}

Robbin and DeCenzo (2005) defines formalization as degree to which jobs are standardized. The nature of formalization refers to the degree to provide employees with rules and procedures that not only deprive but also discourage creativity, autonomous work and learning activity (Miner 1982). When organization reduces rules and regulations, it encourages creative, autonomous work, learning, and organizes work units around core processes to enhance value to customers. In the opinion of Nnabuife (2009), mechanistic system encourage strict bureaucracy: here the activities in the organization are laid down in such a way that objectives and authority of individual are well defined, power flow is known, and adhered to strictly, personal skills are separated and specialized tasks are clearly defined. The organic structure in contrast to mechanistic is where job skills are used in the group settings, communication flows at all levels of the organization and there is less emphasis on taking and giving orders from subordinate to superior and vice versa.

\section{Internal Boundary and External Boundary.}

Organizational boundary is a term used in business and the legal profession mainly to distinguish one company from a separate but related company. It is also used to isolate a company from other external stakeholders as well as internal links. In order to operate effectively and efficiently, an organization must have a good structure with blurred boundaries. The structure of an organization plays two important roles in every organization: structure clarifies the roles for each member of an organization and also dictates the amount of control each member possesses. However, even though structure plays an important and necessary role in an organization, the structure of an organization can also create barriers between people in different parts of the organization and between the organization and stakeholders outside the organization. These barriers or boundaries if too tight can inhibit people from working together and make the organization less efficient and less responsive to the needs of their customers. In order to respond to the changing environment and to provide value to customers, the firm needs to infiltrate the external boundary with customers, suppliers and other companies (Ashkenas, 2002). Loose boundaries facilitate involving Customers extensively and early in product development, product manufacturing, and delivery activities because customers contribute valuable feedback about products or services. 


\section{Technology}

Technology in the opinion of Onodugo (2000) is a technique or complex of techniques employed to alter materials (human or non-human, mental or physical) in an anticipated manner. It is a possibility package of institution, which could be managed or mismanaged with varying degree of success and failures (Imaga, 2003). Technology is the methods and techniques employed in productive methods available to an organization for converting resources into products and services (Griffin, 1996), and factors that are related to knowledge applied and machine used in the production of goods and services which have an impact on the business of the organization (Kamzi,2003). The success, performance and survival of every organization is dangerously dependent on the extent to which its structure matches with the technology adopted and the ability of the organization to respond to changes in technology. The responsiveness of management to respond to changes in technology is a determining factor with regards to the effectiveness of organization. Porter (1983) observes that technology is among the most prominent factors that determine the rules of competition.

Tanja et al (2012) found a positive relationship between enhanced technology and business performance, while Onwuchekwa (1993) submits that environment and technology determine the three basic flows of activities in business organizations namely, input, throughput and the output activities, therefore, the structure adopted by an organization is depended on the technology existing or adopted by the organization. Woodward (1965) in the process of determining the relationship between technology and structure of an organization identified three separate technologies, the unit and small batch, large batch and mass production, and process production. Woodward observes that the more complex the technology, the greater the number of managers and management levels(layers of hierarchy), the span of management of first line decreases from mass to process production and increases from unit to mass production, and the greater the technological complexity of the firm, the larger the clerical and administrative staff. Woodward concludes that for each type of technology, there are specific aspects of structure that were associated with success in each category of firms, and this structure is called appropriate structure.

\section{Employee Performance}

A good performance by employee is necessary for the organization, since an organization's successis dependent upon the employee's creativity, innovation and commitment (Ramlall, 2008). Even though employee productivity and employee job performance seems to be related, performance is in some cases measured as the number and value of goods produced. However, in general, productivity tends to be associated with production-oriented terms (e.g. profit and turnover) while employee performance is linked to efficiency or perception-oriented terms (e.g. supervisory ratings and goal accomplishments. Organizations need good employees and appropriate structure that will enhance their performance. According to Kostiuk et al (1989) most organizations performance is measured by supervisory ratings, supervisory ratings quality, and quantity, dependability and job knowledge and goal accomplishments even though they are highly subjective. This study however will however adopt the variables of employee's performance to include; supervisor's ratings, quality, quantity, effectiveness, efficiency, dependability, job knowledge and goal accomplishments.

\section{Methodology}

\section{Research Design}

Research design according to Eheduru (1995) is the specification of method and procedure for acquiring the information needed for the research. This study used descriptive type of survey design. This design was adopted for this study because it intensively described and analyzed the role of organizational structure on performance brewing firms in Nigeria. The major research instrument used is design questionnaire. 
Organizational Structure and Employee's Performance: A Study of Brewing Firms in Nigeria

Area of Study

The area of the study is both the operational and of top management of five brewing firms in Nigeria. Organizational structure is critical to the functioning of all areas of an organization. The independent variable, organizational structure is represented by nature of level of hierarch, nature of formalization, blurred internal and external boundaries and appropriate technology while the dependent variable, employee performance is represented by supervisors rating, quality and quantity, job knowledge, target accomplishment, efficient and effective, dependable and enthusiastic ability and capability.

\section{Population}

The target population of this study comprise of the total staff, including executive and non-executive directors of five functional brewing firms quoted on the Nigerian Stock Exchange. There are six firms in the brewing sector of Nigeria Stock exchange. Premier brewery was disqualified as a result of not functioning for a long period and Interphat, the producer of Hero brand has just came into the market and also not quoted on the Nigerian Stock Exchange yet. In the opinion of this study their disqualification will have an insignificant effect on the study as both firms control insignificant percentage of the share market in brewing sector. The brewing sector was selected for this study because of its importance to the Nigerian economic growth and as one of the largest and active sectors listed within the Nigerian Stock Exchange. Below is the list of different firms enlisted for this study:

Table3.1. Population of the Study

\begin{tabular}{|l|l|l|c|l|l|}
\hline S/N & COMPANY & No of Staff & No of Directors & Total & $\%$ \\
\hline 1. & Nigerian Breweries Plc. & 3305 & 14 & 3319 & 51 \\
\hline 2. & Guinness Nigeria Plc. & 1336 & 13 & 1349 & 21 \\
\hline 3. & Consolidated Breweries Plc & 1110 & 10 & 1120 & 17 \\
\hline 4. & International Breweries Plc. & 475 & 9 & 484 & 08 \\
\hline 5. & Champion Breweries Plc. & 188 & 8 & 196 & 03 \\
\hline & Total & 6414 & 54 & 6468 & 100 \\
\hline
\end{tabular}

Source: Field Survey, 2016

\section{Sample and Sampling Technique}

Sample is the part of the population diocese for the study. The study will apply Taro Yamani formula to get the sample size. The population is 6468 . Since the population is known and has a large number that runs into thousands, Yamani (1964) is appropriate in determining the sample size. However, the sample size is 376 . The final sample size of 376 is made up of 180 from Nigerian Breweries, 81 from Guinness Breweries, 70 from Consolidated Breweries, 21 from International Breweries, and 19 from Champion Breweries.

\section{Validity of Instrument}

The Instruments were submitted to nine handpicked experts in the field of organization behavior and general management. The experts were asked to review the items in the instrument and determine whether the items would measure the information it was designed to elicit. After some minor modifications, the experts recommended the use of modified instrument for the study. The recommended version was subjected to further validation with Rotated component matrix which retained the entire questionnaire since each value is greater than 0.35 in each row. 
Organizational Structure and Employee's Performance: A Study of Brewing Firms in Nigeria

\section{Reliability of the Instrument}

Reliability of the research instrument is with a view to ascertaining its sustainability for the study. The concept of reliability refers to the tests about the degree to which the study instrument perfect the desired measurements when applied to the desired objectives. Akuezuilo et al(2002) opine that a test is reliable to the degree that it measures accurately and consistently, yielding comparable results when administered many times. The instrument was given to selected people for comments and the process was repeated after one week interval to determine if their initial response would conform to their later comments. The instrument was further subjected to Cronbach's alpha. All variables are reliable since their Cronbach's alpha is greater 0.5.

\section{Statistical Tools for Analysis}

The data gathered were carefully analyzed tested with various statistical tools (descriptive statistics, correlation and t-test) with the aim of providing solutions to the research problems as well as validate or invalidate the research hypotheses

\section{Data Presentation, Analysis and Discussion of Results}

\section{Distribution and Return of Questionnaire.}

Table4.1. Questionnaire Distribution and Returned Table

\begin{tabular}{|l|c|c|c|}
\hline S/N & Questionnaire Features & Number of Respondents & Percentage \\
\hline 1. & Number returned and correctly filled & 325 & 86 \\
\hline 2. & Number returned and not correctly filled & 37 & 10 \\
\hline 3. & Number not returned & 14 & 04 \\
\hline & Total number distributed & 376 & 100 \\
\hline
\end{tabular}

Source: Field Survey, 2016

Three hundred and seventy seven (376) copies of the questionnaire were distributed to the respondents. Out of this number, three hundred and twenty five (325) representing $86 \%$ response rates were correctly filled and returned while fourteen (14) copies representing $4 \%$ were not returned. However, thirty seven representing $10 \%$ were returned but not correctly filled and therefore rejected. The implication is that the analysis of data will be based on three hundred and twenty five (325) representing $86 \%$ that were returned and correctly filled. The response rate and the proportion that was used for analysis were considered to be satisfactory.

Personal Data of Respondents

Table4.2. Personal Data of Respondents

\begin{tabular}{|c|c|c|c|c|c|c|c|c|}
\hline S/N & Category & \multicolumn{5}{|c|}{ Frequency } & Total & $\%$ \\
\hline & & NBPLC & GNPLC & CSPLC & IBPLC & CBPLC & & \\
\hline 1. & Gender & & & & & & & \\
& Male & 112 & 50 & 42 & 16 & 11 & 231 & 71 \\
& Female & 48 & 18 & 18 & 5 & 5 & 94 & 29 \\
\hline & Total & 160 & 68 & 60 & 21 & 16 & 325 & 100 \\
\hline
\end{tabular}


Organizational Structure and Employee's Performance: A Study of Brewing Firms in Nigeria

\begin{tabular}{|c|c|c|c|c|c|c|c|c|}
\hline 2. & $\begin{array}{c}\text { Age } \\
\text { Above } 18-30 \\
31-40 \\
41-50 \\
51-60 \\
\text { Above } 60\end{array}$ & $\begin{array}{l}37 \\
70 \\
20 \\
15 \\
11\end{array}$ & $\begin{array}{c}16 \\
32 \\
11 \\
7 \\
6\end{array}$ & $\begin{array}{c}11 \\
25 \\
7 \\
6 \\
5\end{array}$ & $\begin{array}{c}6 \\
11 \\
4 \\
3 \\
4\end{array}$ & $\begin{array}{l}4 \\
6 \\
2 \\
3 \\
3\end{array}$ & $\begin{array}{c}74 \\
144 \\
44 \\
34 \\
29\end{array}$ & $\begin{array}{c}23 \\
44 \\
14 \\
10 \\
9\end{array}$ \\
\hline & Total & 153 & 72 & 54 & 28 & 18 & 325 & 100 \\
\hline 3. & $\begin{array}{l}\text { Marital Statue } \\
\text { Married } \\
\text { Single } \\
\text { Divorced }\end{array}$ & $\begin{array}{c}123 \\
30 \\
5\end{array}$ & $\begin{array}{c}52 \\
12 \\
3\end{array}$ & $\begin{array}{c}47 \\
11 \\
3\end{array}$ & $\begin{array}{c}18 \\
2 \\
3\end{array}$ & $\begin{array}{c}11 \\
3 \\
2\end{array}$ & $\begin{array}{c}251 \\
58 \\
16\end{array}$ & $\begin{array}{c}77 \\
18 \\
5\end{array}$ \\
\hline & Total & 158 & 67 & 61 & 23 & 16 & 325 & 100 \\
\hline 4. & $\begin{array}{c}\text { Education Qualifications } \\
\text { Masters and above } \\
\text { First Degree/HND } \\
\text { OND/Others }\end{array}$ & $\begin{array}{l}52 \\
70 \\
30\end{array}$ & $\begin{array}{l}22 \\
32 \\
15\end{array}$ & $\begin{array}{l}21 \\
31 \\
12\end{array}$ & $\begin{array}{c}8 \\
11 \\
5\end{array}$ & $\begin{array}{l}6 \\
7 \\
3\end{array}$ & $\begin{array}{c}109 \\
151 \\
65\end{array}$ & $\begin{array}{l}34 \\
46 \\
20\end{array}$ \\
\hline & Total & 152 & 69 & 64 & 24 & 16 & 325 & 100 \\
\hline 5. & $\begin{array}{c}\text { Position/Designation } \\
\text { Director } \\
\text { Managers } \\
\text { Supervisors } \\
\text { Others }\end{array}$ & $\begin{array}{l}15 \\
51 \\
41 \\
45\end{array}$ & $\begin{array}{c}9 \\
20 \\
17 \\
22\end{array}$ & $\begin{array}{c}6 \\
22 \\
14 \\
15\end{array}$ & $\begin{array}{l}6 \\
9 \\
6 \\
7\end{array}$ & $\begin{array}{l}6 \\
5 \\
5 \\
4\end{array}$ & $\begin{array}{c}42 \\
107 \\
83 \\
93\end{array}$ & $\begin{array}{l}12 \\
35 \\
25 \\
28\end{array}$ \\
\hline & Total & 152 & 68 & 57 & 28 & 20 & 325 & 100 \\
\hline 6. & $\begin{array}{c}\text { Years of Experience } \\
10 \text { years and below } \\
11-20 \text { years } \\
21-30 \text { years } \\
\text { Above } 30 \text { years }\end{array}$ & $\begin{array}{l}42 \\
57 \\
40 \\
11\end{array}$ & $\begin{array}{c}21 \\
23 \\
20 \\
9\end{array}$ & $\begin{array}{c}15 \\
21 \\
12 \\
5\end{array}$ & $\begin{array}{c}7 \\
9 \\
11 \\
3\end{array}$ & $\begin{array}{l}4 \\
5 \\
7 \\
3\end{array}$ & $\begin{array}{c}89 \\
115 \\
90 \\
31\end{array}$ & $\begin{array}{l}27 \\
35 \\
28 \\
10\end{array}$ \\
\hline & Total & 150 & 73 & 53 & 30 & 19 & 356 & 100 \\
\hline
\end{tabular}

Source: Field Survey, 2014

From table 4.2 above, it shows that the gender of respondents is made up of 231(71\%) male and 94(29\%) female. The ages of the respondents is $218(67 \%)$ for 40 and below, 78(24\%) for 41 to 60 and 29(9\%) for 61 and above. The marital status of respondent is made up of 251 (77\%) married, 58(18\%) single, and 16(5\%) divorced. Positions or levels of respondents shows that $42(12 \%)$ are directors, $107(35 \%)$ are Managers, $83(25 \%)$ are Supervisors while 93(25\%) are below supervisors level. The academic qualifications of respondents attest that majority of workforce 260(80\%) are graduates and above while 65(20\%) were OND and below. The years of experience of respondents in their organizations shows that $89(27 \%)$ of respondents have spent ten years and below, $115(35 \%)$ eleven to twenty years, $90(28 \%)$ twenty one to thirty years while $31(10 \%)$ spend above thirty years. 
Organizational Structure and Employee's Performance: A Study of Brewing Firms in Nigeria

Table4.3. Descriptive Statistics for Variables in Nature of Hierarchical Layers

\begin{tabular}{|c|c|c|c|c|c|c|}
\hline & & $\mathbf{N}$ & Minimum & Maximum & Mean & $\begin{array}{c}\text { Std. } \\
\text { Deviation }\end{array}$ \\
\hline & Organizational layers & $\mathbf{0}$ & & & & \\
\hline 1 & My company has few layers in hierarchy & 325 & 3.00 & 5.00 & 4.47 & 0.821 \\
\hline 2 & $\begin{array}{l}\text { As a result of few layers in my company, } \\
\text { decisions do not take longer time }\end{array}$ & 325 & 3.00 & 5.00 & 3.81 & 0.741 \\
\hline 3 & $\begin{array}{l}\text { Few layers in my organizations enable a } \\
\text { high level of integration, certain decision } \\
\text { are not always taken at higher level but } \\
\text { operational level due to decentralization }\end{array}$ & 325 & 3.00 & 5.00 & 4.41 & 0.862 \\
\hline 4 & $\begin{array}{l}\text { Certain decision are not always taken at } \\
\text { higher level but operational level due to } \\
\text { decentralization as a result of few layers }\end{array}$ & 325 & 3.00 & 5.00 & 4.41 & 0.861 \\
\hline 5 & $\begin{array}{l}\text { Engaging lower employees in the } \\
\text { decision making facilitate employee } \\
\text { empowerment and sense of } \\
\text { belongingness. }\end{array}$ & 325 & 3.00 & 5.00 & 4.47 & 0.823 \\
\hline 6 & $\begin{array}{l}\text { Reducing layers and empowering low } \\
\text { level employees facilitate employee's } \\
\text { devotion to the vision and objective of } \\
\text { our organization by employees. }\end{array}$ & 325 & 3.00 & 5.00 & 3.81 & 0.744 \\
\hline 7 & $\begin{array}{c}\text { Fewer layers enhances better } \\
\text { communication within the organization }\end{array}$ & 325 & 3.00 & 5.00 & 4.41 & 0.865 \\
\hline
\end{tabular}

Source: Researcher's Field Survey Result (2016)

Table4.4. Descriptive Statistics for Variables in Nature of Formalization

\begin{tabular}{|l|c|c|c|c|c|c|}
\hline & Formalization & N & Minimum & Maximum & Mean & $\begin{array}{l}\text { Std. } \\
\text { Deviation }\end{array}$ \\
\hline $\mathbf{8}$ & $\begin{array}{c}\text { My company do not apply too much } \\
\text { rules and regulations to its employees }\end{array}$ & 325 & 3 & 5 & 3.97 & 1.137 \\
\hline $\mathbf{9}$ & $\begin{array}{c}\text { Reducing rules and regulations do } \\
\text { encourage creative. }\end{array}$ & 325 & 3 & 5 & 4.54 & 0.751 \\
\hline $\mathbf{1 0}$ & $\begin{array}{c}\text { Less formalization facilitate } \\
\text { communication within my company }\end{array}$ & 325 & 3 & 5 & 3.56 & 1.082 \\
\hline $\mathbf{1 1}$ & $\begin{array}{c}\text { Less formalization encourages creativity } \\
\text { and learning in my company }\end{array}$ & 325 & 3 & 5 & 4.47 & 0.802 \\
\hline $\mathbf{1 2}$ & $\begin{array}{c}\text { Less formalization in my company } \\
\text { facilitates employee empowerment and } \\
\text { sense of belongingness. }\end{array}$ & 325 & 2 & 5 & 3.42 & 1.086 \\
\hline
\end{tabular}


Organizational Structure and Employee’s Performance: A Study of Brewing Firms in Nigeria

\begin{tabular}{|c|c|c|c|c|c|c|}
\hline 13 & $\begin{array}{c}\text { reducing rules and regulation } \\
\text { encourages initiatives from all levels of } \\
\text { employee }\end{array}$ & 325 & 3 & 5 & 3.76 & 0.728 \\
\hline 14 & $\begin{array}{l}\text { Less formalization facilitate creativity } \\
\text { and innovation }\end{array}$ & 325 & 3 & 5 & 4.39 & 0.861 \\
\hline
\end{tabular}

Source: Researcher's Field Survey Result (2016)

Table4.5. Descriptive Statistics for Variables in nature of internal and external boundaries

\begin{tabular}{|c|c|c|c|c|c|c|}
\hline & & $\mathbf{N}$ & Minimum & Maximum & Mean & $\begin{array}{l}\text { Std. } \\
\text { Deviation }\end{array}$ \\
\hline & Internal and external boundaries & & & & & \\
\hline 15 & $\begin{array}{c}\text { My organization has blurred internal } \\
\text { boundaries that allow easy relationship } \\
\text { with various units and department of the } \\
\text { organization }\end{array}$ & 325 & 3 & 5 & 4.46 & 0.823 \\
\hline 16 & $\begin{array}{c}\text { Blurred boundaries enables effective } \\
\text { cooperation and coordination between } \\
\text { different role-players my in organization, } \\
\text { coordination and cooperation enhances } \\
\text { performance of my organization }\end{array}$ & 325 & 3 & 5 & 3.75 & 0.727 \\
\hline 17 & $\begin{array}{l}\text { The open boundaries in my company } \\
\text { enables free communication with } \\
\text { customers, suppliers and other companies }\end{array}$ & 325 & 2 & 5 & 4.77 & 0.802 \\
\hline 18 & $\begin{array}{c}\text { My company receives inputs from } \\
\text { Customers and other stakeholders } \\
\text { extensively in product development, } \\
\text { production, and delivery activities as a } \\
\text { result of open access. }\end{array}$ & 325 & 3 & 5 & 4.39 & 0.861 \\
\hline 19 & $\begin{array}{c}\text { Feedback from our Customers contributes } \\
\text { immensely to our good products or } \\
\text { services. }\end{array}$ & 325 & 3 & 5 & 3.55 & 1.082 \\
\hline 20 & $\begin{array}{c}\text { Our suppliers and other companies } \\
\text { contribute valuable suggestions, technical } \\
\text { contributions, and quality improvement } \\
\text { actions that improve our products }\end{array}$ & 325 & 3 & 5 & 4.46 & 0.823 \\
\hline 21 & $\begin{array}{l}\text { Breaking internal boundaries to ensure } \\
\text { coordinated action, infiltrating external } \\
\text { boundaries between customers and } \\
\text { suppliers to cope with the increasing } \\
\text { complexity and dynamics of the } \\
\text { environment }\end{array}$ & 325 & 2 & 5 & 4.34 & 0.870 \\
\hline
\end{tabular}

Source: Researcher's Field Survey Result (2016) 
Organizational Structure and Employee's Performance: A Study of Brewing Firms in Nigeria

Table4.6. Descriptive Statistics for Variables in technology

\begin{tabular}{|l|l|c|c|c|c|c|}
\hline & & N & Minimum & Maximum & Mean & $\begin{array}{l}\text { Std. } \\
\text { Deviation }\end{array}$ \\
\hline $\mathbf{2 2}$ & $\begin{array}{l}\text { Technology } \\
\text { Our structure matches with the technology } \\
\text { of my company. }\end{array}$ & 325 & 2 & 5 & 4.42 & 0.990 \\
\hline $\mathbf{2 3}$ & $\begin{array}{l}\text { The responsiveness of our management } \\
\text { to respond to changes in technology is a } \\
\text { determining factor to the effectiveness of } \\
\text { organization. }\end{array}$ & 325 & 3 & 5 & 3.572 & 1.131 \\
\hline $\mathbf{2 4}$ & $\begin{array}{l}\text { Appropriateness of our Technology } \\
\text { contributes largely to our management } \\
\text { effectiveness }\end{array}$ & 325 & 2 & 5 & 4.28 & 0.917 \\
\hline $\mathbf{2 5}$ & $\begin{array}{l}\text { The matching of Our technology with } \\
\text { our structure contributes to the success, } \\
\text { performance and survival our company, }\end{array}$ & 325 & 2 & 5 & 4.05 & 1.117 \\
\hline $\mathbf{2 6}$ & $\begin{array}{l}\text { Each type of technology has a specific } \\
\text { organizational structure that will match it }\end{array}$ & 325 & 3 & 5 & 4.27 & 0.882 \\
\hline $\mathbf{2 7}$ & $\begin{array}{l}\text { Our organizations always scan the } \\
\text { technological environment to determine } \\
\text { what technology will mean to existing } \\
\text { structure and products }\end{array}$ & 325 & 3 & 5 & 3.90 & 0.742 \\
\hline $\mathbf{2 8}$ & $\begin{array}{l}\text { The nature of our technology and the } \\
\text { structure adopted by our company } \\
\text { contribute to employee's performance. }\end{array}$ & 325 & 3 & 5 & 4.54 & 0.751 \\
\hline
\end{tabular}

Source: Researcher's Field Survey Result (2016)

Table4.7. Descriptive Statistics for Variables in Employee's Performance

\begin{tabular}{|c|c|c|c|c|c|c|}
\hline & & $\mathbf{N}$ & Minimum & Maximum & Mean & $\begin{array}{l}\text { Std. } \\
\text { Deviation }\end{array}$ \\
\hline & Employee performance & & & & & \\
\hline 29 & $\begin{array}{l}\text { The rating of employee's performance by the } \\
\text { management is always high. }\end{array}$ & 325 & 3 & 5 & 3.74 & 0.861 \\
\hline 30 & $\begin{array}{l}\text { Job knowledge in our company is factor of } \\
\text { our good performance. }\end{array}$ & 325 & 2 & 5 & 4.77 & 0.802 \\
\hline 31 & $\begin{array}{l}\text { Quantity and quality is one of the measures } \\
\text { adopted by our management to measure } \\
\text { employee performance. }\end{array}$ & 325 & 3 & 5 & 4.35 & 0.861 \\
\hline 32 & $\begin{array}{l}\text { Goal accomplishments is the objective of } \\
\text { both the management and all employees }\end{array}$ & 325 & 3 & 5 & 3.55 & 1.083 \\
\hline 33 & $\begin{array}{l}\text { Our staff members are not only efficient but } \\
\text { effective }\end{array}$ & 325 & 3 & 5 & 4.36 & 0.824 \\
\hline
\end{tabular}


Organizational Structure and Employee's Performance: A Study of Brewing Firms in Nigeria

\begin{tabular}{|l|l|c|c|c|c|c|}
\hline 34 & $\begin{array}{l}\text { Our staff are high dependable and } \\
\text { enthusiastic }\end{array}$ & 325 & 2 & 5 & 4.34 \\
\hline $\mathbf{3 5}$ & $\begin{array}{l}\text { Our workforce has both job knowledge and } \\
\text { prerequisite skill. }\end{array}$ & 325 & 3 & 5 & 4.48 & 0.823 \\
\hline
\end{tabular}

Source: Researcher's Field Survey Result (2016)

\section{Test of Hypotheses}

This research used 5\% level of significance $\alpha=0.05$ (or $95 \%$ level of confidence). This means that, the null hypothesis will be rejected only if the sample result is so different from the hypothesized value and the different of that amount smaller and larger would occur by chance with a probability of 0.05 or less. This can also mean that, there is a $95 \%$ chance that the sample is distributed in the same way as the population and that there is only $5 \%$ making errors.

Decision rule: We reject $\mathrm{H}_{0}$ if F-calculated is greater than F-tabulated, however, if p-value is also less than 0.05 ., otherwise we accept.

Table4.8. Paired Samples Correlations

\begin{tabular}{|c|c|c|c|c|}
\hline & T-test & N & Correlation & Sig. \\
\hline Pair 1 & $\begin{array}{c}\text { Employee performance \& hierarchical } \\
\text { layers }\end{array}$ & 7 & 0.715 & 0.023 \\
\hline Pair 2 & $\begin{array}{c}\text { Employee performance \& nature of } \\
\text { formalization }\end{array}$ & 7 & 0.921 & 0.000 \\
\hline Pair 3 & $\begin{array}{c}\text { Employee performance \& internal and } \\
\text { external boundaries }\end{array}$ & 7 & 0.989 & 0.000 \\
\hline Pair 4 & Employee performance \& technology & 7 & 0.609 & 0.065 \\
\hline
\end{tabular}

Source: Researcher's Field Survey Result (2016)

Table4.9. Paired Samples Test

\begin{tabular}{|c|c|c|c|c|c|c|c|c|c|}
\hline & & \multicolumn{5}{|c|}{ Paired Differences } & \multirow[t]{3}{*}{ T-test } & \multirow[t]{3}{*}{ D.f } & \multirow{3}{*}{$\begin{array}{c}\text { Sig. } \\
\text { (2-tailed) }\end{array}$} \\
\hline & & \multirow[t]{2}{*}{ Mean } & \multirow[t]{2}{*}{ SD } & \multirow[t]{2}{*}{$\begin{array}{l}\text { Std. } \\
\text { Error } \\
\text { Mean }\end{array}$} & \multicolumn{2}{|c|}{$\begin{array}{l}\text { 95\% Confidence } \\
\text { Interval of the } \\
\text { Difference }\end{array}$} & & & \\
\hline & & & & & Lower & Upper & & & \\
\hline Pair 1 & $\begin{array}{c}\text { Employee } \\
\text { Performance- } \\
\text { hierarchical layers }\end{array}$ & 0.374 & 0.388 & 0.136 & 0.056 & 0.678 & 2.659 & 6 & 0.021 \\
\hline Pair 2 & $\begin{array}{c}\text { Employee } \\
\text { performance- } \\
\text { nature of } \\
\text { formalization }\end{array}$ & 0.369 & 0.377 & 0.132 & 0.044 & 0.657 & 2.455 & 6 & 0.031 \\
\hline
\end{tabular}


Organizational Structure and Employee's Performance: A Study of Brewing Firms in Nigeria

\begin{tabular}{|c|c|c|c|c|c|c|c|c|c|}
\hline \hline Pair 3 & $\begin{array}{c}\text { Employee } \\
\text { performance- } \\
\text { internal and } \\
\text { external } \\
\text { boundaries }\end{array}$ & 0.171 & 0.292 & 0.091 & -0.037 & 0.379 & 1.861 & 6 & 0.045 \\
\hline Pair 4 & $\begin{array}{c}\text { Employee } \\
\text { performance- } \\
\text { technology }\end{array}$ & 0.566 & 0.432 & 0.158 & 0.188 & 0.898 & 3.553 & 6 & 0.007 \\
\hline
\end{tabular}

Source: Researcher's Field Survey Result (2016)

\section{DiscusSion OF FINDINGS}

The question for objective 1 was designed to determine whether nature of hierarchical layer has significant effect on employee's performance using research question 1 to 7 . The questionnaire items were validated with Rotated component matrix which retained all the items in the questionnaire since each value is greater than 0.35 in each row while the reliability was confirmed with Cronbach's Alpha. The items are reliable since their cronbach's alpha is 0.728 .

With descriptive statistics, the mean responses for both variables from research questions 1 to 7 were above 3.5 at 5 point Likert scale which confirm that respondents agreed to issues raised in the questionnaire. To test whether there is correlation between organizational structure and firm's performance, confirmed a correlation value of 0.715 . This shows that firm's performance and Organizational Structure are positively related.

To test the hypothesis, a t- test was conducted at $5 \%$ level of significance. The result from t-test attests that tcal of 2.659 is greater than $\mathrm{t}_{\text {tab }} 1.833$, and the p-value of 0.021 is less than 0.05 and the null hypothesis was rejected. We hereby agree that nature of hierarchical layers has significant positive effect on firm's performance. This result is in agreement with Macduffie et al, (1995) which posits that there is positive relationship between structure that has with few layers in hierarchy and integration of organizational members which further lead to better performance by the employees.

The question for objective 2 was designed to determine whether nature of formalization has significant effect on employee's performance using research question 8-14. The questionnaire items were validated with Rotated component matrix which retained the entire questionnaire since each value is greater than 0.35 in each row while the reliability was confirmed with Cronbach's Alpha. The items are reliable since their cronbach's alpha is 0.78 .

With descriptive statistics, the mean responses for both variables from research questions 8-14 were above 3.5 in five point Likert scale which confirm positive. To test whether there is correlation between respond to technological change and firm'sperformance, Table 4.8 confirmed a correlation value of 0.921 . This shows that firm's performance and respond to technological change are positively related.

To test the hypothesis, a t- test was conducted at $5 \%$ level of significance. The result from t-test attests that tcal of 2.455 is greater than $t_{\text {tab }} 1.833$, and the p-value of 0.031 is less than 0.05 and the null hypothesis was rejected. We hereby agree that the nature of formalization in organization has significant positive effect on firm's performance. This result is in line with the position of Miner (1982) who posits that high degree to provide employees with rules and procedures that not only deprive but also discourage creativity, autonomous work and learning activity. However, reducing rules and regulations to encourage creative, autonomous work and learning, organizing work units around core processes to enhance value to customers and higher employee performance. 
The question for objective 3 was designed to ascertain whether lose internal and external boundaries has significant effect on employee's performance using research question 15-21. The questionnaire items were validated with Rotated component matrix which retained the entire questionnaire since each value is greater than 0.35 in each row while the reliability was confirmed with Cronbach's Alpha. The items are reliable since their cronbach's alpha is 0.0 .639 .

With descriptive statistics, the mean responses for both variables from research questions 15 and 21 were above 3.5 in 5 Likert points which confirm positive. To test whether there is correlation between lose internal and external boundaries and employee's performance, Table 4.8 confirmed a correlation value of 0.879 . This shows that employee's performance and lose internal and external boundaries are positively related. To test the hypothesis, a t- test was conducted at $5 \%$ level of significance. The result from $t$-test attest that $t_{\text {cal }}$ of 1.861 is greater than $t_{\text {tab }}$ of 1.833 , and the p-value of 0.045 is less than 0.05 and the null hypothesis was therefore rejected. We hereby agree that lose internal and external boundaries has significant positive effect on employee's performance. This result is in agreement with Ashkenas (2002) who maintains that firms that infiltrate internal and external boundaries perform better than those that do not.

The question for objective 4 was designed to ascertain whether technology has significant effect on firm's performance using research question 22 to 28 . The questionnaire items were validated with Rotated component matrix which retained the entire questionnaire since each value is greater than 0.35 in each row while the reliability was confirmed with Cronbach's Alpha. The items are reliable since their cronbach's alpha is 0.653. Whereas, the descriptive statistics, the mean responses for both variables from research questions 22 and 28 were above 3.5 in 5 Likert points which confirm positive. To test whether there is correlation between Merger/ acquisition and firm's performance, Table 4.8 confirmed a correlation value of 0.609 . This shows that firm's performance and Merger/acquisition are positively related. To test the hypothesis, a t- test was conducted at $5 \%$ level of significance. The result from $t$-test attest that $t_{\text {cal }}$ of 3.553 is greater than $t_{\text {tab }}$ of 1.833 , and the $p$-value of 0.007 is less than 0.05 and the null hypothesis was therefore rejected. We hereby agree that technology has significant positive effect on firm's performance.

\section{CONCLUSION AND RECOMMENDATION}

The basic and fundamental goal of every organization is performance, survival and growth. However, the surest means of maintaining performance, survival and growth of organizations is having the right human resources in terms of size and quality. Having the right human resources is directly related to the structure in which organization operates. The goal of the research was to determine the effects of organizational structure on employee's performance. All hypotheses are supported, which indicates significant relationships among the dimensions of organizational structure and employee's performance. This supports the claim that the firms that reduce hierarchy layers, have blurred internal boundaries and infiltrated external boundaries, have lower degree of formalization, and adopt appropriate technology that suits its structure would have higher employees' performance. The results imply that there are several aspects of organizational structure to enhance employee's performance. Therefore, organizations seeking higher employee's performance should consider the important role played by four six structural dimensions. Studies have shown that firms that fail to design appropriate structure that will suit organizational workforce will definitely encounter the problem performance from its employees. In view of this, the study concludes that organizational structure has a significant positive effect with the employee's performance.

In line with the objective of this study in finding ways of addressing structural issues with a view of enhancing employee's performance, the following are the recommendations as established by the research; The study therefore recommends among others that Nigeria firms should give more serious attention in designing an appropriate structure that must match all units and component parts of organization to facilitate employee's performance.

American Research Journal of Business and Management

Page 14 
1. Organizations are encouraged to adopt lesser layer in organizational hierarchy. Fewer layers facilitate enables a high level of integration of organizational members, quick response and decentralized decision-making.

2. That organizations are advised to reduce applying too rigid rules. High degree of rules not only deprives employees from using his initiative but also discourage creativity, autonomous work and learning activity.

3. That organization should encourage blurred internal which will engender corporation and coordination among all units, departments and individual employees. Also lose a external boundaries need to be encouraged in order to respond to the changing environment and to provide value to customers, the firm need to infiltrate the external boundary with customers, suppliers and other companies

4. That organization isencouraged not only to adopt the appropriate technology while designing the structure but also always to respond to changes in technology. This is because technology is a determining factor with regards to the effectiveness of organization and as well among the most prominent factors that determine the rules of competition.

\section{REFERENCES}

1. Akinyele S. T. (2011). "Significance of strategic marketing to enterprise performance: An empirical analysis of Nigerian oil and gas industry", Global Journal of Management and Business Research, Vol. 10, No. 6, pp. 60-77.

2. Ashkenas, D., Ulrich, D. \&Jick T. The Boundaryless Organization: Breaking the Chains of Organizational Structure [M]. Mechanical Industry Press, 2002:75-112

3. Bucic T. and Gudergan S. (2004). "The impact of organizational settings on creativity and learning in alliances", Management, Vol. 7,pp. 257-273.

4. Customization (1993): The New Frontier in Business Competition[M]. Boston: Harvard Business School Press, 1993

5. Hajipour B., Mohammad T. and Arash S. (2011).'An investigation of the relationships between industry structure, strategy type, organizational characteristics and organizational performance: A case study of the food and chemical industries of Iran", AfricanJournal of Business Management, Vol. 5, No. 16, pp. 7085-7098.

6. Kamzi, A. (2003), Business Policy and strategic Management, New Delhi: Tata McGraw-Hill publishing Company Limited.

7. Lenz R. T. (1980). "Determinants of organizational performance: An interdisciplinary review",Strategic Management Journal, Vol. 2,No. 2, pp. 131-154.

8. Likert, T. (1932) in Uebersax (2006), The Technique for Measurement of Attitude, Retrieved from// www.performancezoom.com/performance_fichiers/likert.gi on $20^{\text {th }}$ September, 2014

9. Macduffie, J.P. (1995), Human Resource Bundles and Manufacturing Performance: Organizational Logic and Flexible Production Systems in the World Auto Industry, Industrial and Labor Relations Review, 1995, (48):197-221

10. Mansoor N., Aslam H. D., Barbu C. M., Capusneanu S. and Lodhi M. A. (2012). "Organizational structure as determinant of organizational performance, uncovering essential facets of organic and mechanistic structure", American Journal of ScientificResearch, Vol. 55, pp. 48-55 
Organizational Structure and Employee's Performance: A Study of Brewing Firms in Nigeria

11. Nahm,Ay.,Vonderembse, M.A \&Koufteros, X. (2003)The Impact of Organizational Structure on Time-based Manufacturing and Performance[J]. Journal of Operations Management 2003, (21):281-306

12. Nwosu, H. (2015), strategic planning and organizational performance: A Study of Selected Brewing Firms in Nigeria. The International Journal of Business \& Management Vol 3 Issue 2, 162-186

13. Nnabuife, Ezimma. (2009), Organizational Behaviour and Management Theory, Nimo: Rex Charles \& Patrick Limited.

14. Onodugo, V. (2000), Management Fundamentals and Practices, Enugu: El Demark Ltd.

15. Onwuchekwa, C. I. (2000), Business Policy and Strategic Management, Onitsha: Varsity Press.

16. Oso .W. and Onen .D, (2009), A General Guide to writing Research proposal and Report.Nairobi; Option Press and Publication.

17. Oyedijo, Ade. (2012), "Antecedents and Performance Outcomes of Strategic Planning Nigeria Public Universities", International Journal of Asian Social Science, 2012, vol. 2, issue 4, pages 448-461.

18. Oyewobi A. O., Windapo K. S. and Rotimi J. O. B. (2013).“Impact of organizational structure and strategies on construction organizations performance", University of Cape Town, South Africa and Auckland University of Technology, New Zealand. Pine, B. Mass

19. Porter, M. (1983), Competitive Strategy: Techniques for Analyzing Industries and Competitors, New York: Free Press

20. Robbin S. P. and DeCenzo D. A. (2005).Fundamentals of Management: Essential Concepts and Applications, Prentice Hall, Upper Saddle River, NJ.

21. Tanja A., Borka, B. \&Vlado, D. (2012), The impact of Technology-enhanced Organizational Learning on Business Performance - An Empirical Study, Journal of East European

22. Vickery, S., C. Droge\& R. Germain (1999), The Relationship Between Product Customization and Organizational Structure, Journal of Operations Management, 1999, (17):377-391

23. Waweru M. A. (2008). "Competitive strategy implementation and its effect on performance in large private sector firms in Kenya", unpublished Ph.D. thesis, University of Nairobi.

24. Yamane, T. (1964), Statistics: An Introductory Analysis ( $3^{\text {rd }}$ eds), New York: Harper and Row Publishers, Management Studies, vol.17, issue 3, pp.369-383.

Citation: Malik Shahzad Shabbir, “Organizational Structure and Employee's Performance: A Study of Brewing Firms in Nigeria". American Research Journal of Business and Management; V3, I1; pp:1-16

Copyright (c) 2017 Malik Shahzad Shabbir, This is an open access article distributed under the Creative Commons Attribution License, which permits unrestricted use, distribution, and reproduction in any medium, provided the original work is properly cited. 